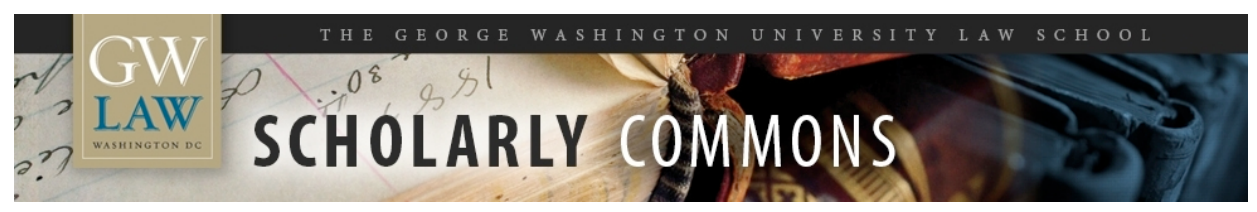

\title{
Codification, Progressive Development, or Scholarly Analysis? The Art of Packaging the ILC's Work Product
}

\author{
Sean D. Murphy \\ George Washington University Law School, smurphy@law.gwu.edu
}

Follow this and additional works at: https://scholarship.law.gwu.edu/faculty_publications

Part of the Law Commons

\section{Recommended Citation}

Sean D. Murphy, Codification, Progressive Development, or Scholarly Analysis? The Art of Packaging the ILC's Work Product in The Responsibility of International Organizations: Essays in Memory of Sir lan Brownlie (Maurizio Ragazzi, ed., 2013).

This Book Part is brought to you for free and open access by the Faculty Scholarship at Scholarly Commons. It has been accepted for inclusion in GW Law Faculty Publications \& Other Works by an authorized administrator of Scholarly Commons. For more information, please contact spagel@law.gwu.edu. 


\title{
Codification, Progressive Development, or Scholarly Analysis? The Art of Packaging the ILC's Work Product
}

\author{
forthcoming in THE RESPONSIBILITY OF INTERNATIONAL ORGANIZATIONS: ESSAYS IN MEMORY OF \\ SIR IAN BROWNLIE (Maurizio Ragazzi, ed.) (Martinus Nijhoff) (2013).
}

\section{Sean D. Murphy}

I. Introduction

Due to his extraordinary accomplishments as a scholar, a practitioner, and a professor for legions of doctoral students, Ian Brownlie was a giant in the field of international law. Serving on the International Law Commission from 1997 to 2008, Brownlie was present during one of the most interesting periods of change in the way the ILC finalized its work, a period that in some respects climaxed with its draft articles on the responsibility of international organizations. As a tribute to Brownlie's contributions to the field of international law, this essay briefly addresses the "art of packaging" the ILC's work product, a topic which has considerable implications for the Commission's own legacy within the field.

There are two key choices that must be made by the Commission when "packaging" the outcome of a topic. First, the Commission must decide what it will call the product, having a menu of possibilities: "draft convention"; "draft articles"; "principles"; "guidelines"; "report"; and so on. Second, once finalized, the Commission must decide what to say when sending the work product to the General Assembly, including whether to recommend that it be transformed into an international convention.

The Commission's project on the responsibility of international organizations was completed in the form of sixty-seven "draft articles," along with associated commentary. Those draft articles were sent to the General Assembly with a recommendation that the Assembly "take note of the draft articles ... in a resolution, and annex them to the resolution" and "consider, at a later stage, the elaboration of a convention on the basis of the draft articles. ${ }^{1}$ While some of the rules set forth in the draft articles are non-controversial, others are much less settled, due to a dearth of practice and an uncertainty as to whether rules on responsibility that apply to States should apply mutatis mutandis to international organizations. Consequently, a further part of the "packaging" of these draft articles was the inclusion in the ILC's general commentary of a statement that the "fact that several of the present draft articles are based on limited practice moves the border between codification and progressive development in the direction of the latter. ... In other words, the provisions of the present draft articles do not necessarily yet have the same authority as the corresponding provisions on State responsibility.",

\footnotetext{
${ }^{1}$ Report of the International Law Commission on the Work of Its Sixty-Third Session, Gen. Ass. Off. Recs., Sixty-sixth Session, Supp. No. 10, at 53, para. 85 (A/66/10).

${ }^{2} I d$. at 70.
} 
Understanding the significance and reason for such a statement requires some understanding of the broader ways in which the Commission completes its work product, and how such "packaging" has changed over time.

\section{Draft Conventions}

As is well known, the Statute of the ILC originally envisaged two different types of projects by the Commission: "progressive development" projects and "codification" projects. A project that progressively developed the law, by definition, created new rules, in that it addressed "subjects which have not yet been regulated by international law or in regard to which the law has not yet been sufficiently developed in the practice of States." Progressive development could only be done by means of a convention ${ }^{3}$ and it was thought that the General Assembly would be the prime initiator of proposals in that regard, ${ }^{4}$ though proposals might also be advanced by other U.N. organs or specialized agencies, or by U.N. Member States. ${ }^{5}$

There have been just two projects expressly concluded by the ILC as "conventions," both early in the life of the Commission. In 1954, the ILC adopted the Draft Convention on the Elimination of Future Statelessness, ${ }^{6}$ which was never developed into a treaty by States. The same year it adopted the Draft Convention on the Reduction of Future Statelessness, ${ }^{7}$ which led to the 1961 Convention on the Reduction of Statelessness. ${ }^{8}$ Both conventions were proposed by the Economic and Social Council, which in 1950 urged "that the International Law Commission prepare at the earliest possible date the necessary draft international convention or conventions for the elimination of statelessness." 9

Early in its existence, the Commission found that the distinction between "progressive development" and "codification" of the law was not sustainable in practice; in most areas there were both settled rules and gaps requiring the development of new rules. Moreover, ILC Members would often differ as to whether a particular rule already existed or was being developed by the Commission. As such, the Commission stopped advancing any of its

\footnotetext{
${ }^{3}$ See Statute of the International Law Commission, Art. 15 (ILC Statute) ("In the following articles the expression progressive development of international law is used for convenience as meaning the preparation of draft conventions on subjects which have not yet been regulated by international law or in regard to which the law has not yet been sufficiently developed in the practice of States.").

${ }^{4} I d$., Art. 16.

${ }^{5}$ Id., Art. 17(1).

${ }^{6}$ See Report of the International Law Commission on the Work of its Sixth Session, Gen. Ass. Off. Recs., Ninth Session, Supp. No. 10, at para. 25 (A/9/10).

${ }^{7} I d$.

${ }^{8}$ Convention on the Reduction of Statelessness, 989 U.N.T.S .175.

${ }^{9}$ ECOSOC Res. 319 B (XI) (Aug. 11, 1950); see also ECOSOC Res. 304 D (XI) (July 17, 1950).
} 
projects as draft "conventions," since that term might have conveyed a view that the entire project was one of progressive development.

Even so, one recent project might be thought to fall into this category: the ILC's 1994 "Draft Statute" for an International Criminal Court, with commentaries, ${ }^{10}$ which led to the 1998 treaty entitled "Rome Statute of the International Criminal Court." "The project was proposed by the U.N. General Assembly, which in 1992 requested "the International Law Commission to continue its work on [the] question [of international criminal jurisdiction] by undertaking the project for the elaboration of a draft statute for an international criminal court as a matter of priority as from its next session, ... with a view to drafting a statute ...." 12 The term "statute," however, was not synonymous with "convention," for at the time it was not clear what form the new court would take. While the court might have been established by a multilateral treaty, the Commission also contemplated the possibility of the court being created either as a new organ of the United Nations (through amendment of the Charter) or as a subsidiary organ of the Security Council (such as had occurred with the International Criminal Tribunal for the former Yugoslavia). ${ }^{13}$ As such, the term "statute" was a neutral expression adaptable to whatever means might ultimately be used for establishing the court.

\section{Draft Articles}

As noted above, the ILC Statute also envisaged "codification" projects, by which was meant "the more precise formulation and systematization of rules of international law in fields where there already has been extensive State practice, precedent and doctrine." ${ }^{14}$ In the period prior to adoption of the ILC Statute, many government representatives thought that a codification project should not be concluded as an international convention. As the U.N. Secretariat noted during the drafting of the ILC Statute, "the failure of governments to reach agreement, for political reasons, in a conference convened to codify rules of international law, would seem to cast doubt upon certain rules of international law whose validity had been admitted for a very long time and which had hitherto generally been assumed to be part of customary international law.", 15

For a majority of the drafters of the ILC Statute (led by the U.K. delegate, James Brierly), codification projects were largely a "scientific" task, in which knowledgeable

\footnotetext{
${ }^{10}$ See Report of the International Law Commission on the Work of its Forty-Sixth Session, Gen. Ass. Off. Recs., Forty-Ninth Session, Supp. No. 10, at 26 (A/49/10).

${ }^{11}$ Rome Statute of the International Criminal Court, July 17, 1998, 2187 U.N.T.S. 3.

${ }^{12}$ G.A. Res. 47/33, para. 6 (Nov. 25, 1992).

${ }^{13}$ See Report of the International Law Commission on the Work of its Forty-Sixth Session, Gen. Ass. Off. Recs., Forty-ninth Session, Supp. No. 10, at 73-74 (A/49/10).

${ }^{14}$ ILC Statute, Art. 15.

${ }^{15}$ Memorandum on Methods for Encouraging the Progressive Development of International Law and Its Eventual Codification, U.N. Doc. A/AC.10/7, at 7 (May 6, 1947); see generally R. Dhokalia, The Codification of Public International Law (Manchester, 1971), 203-16.
} 
"jurists" can carefully identify and declare the rules that already exist. The persuasive authority of such "restatements" would turn on their intrinsic merits, though over time States might decide to endorse the product officially through a General Assembly resolution or by turning it into an international convention. A minority group (led by the Soviet delegate,Vladimir Koretsky), thought that all Commission projects should culminate in an international convention. ${ }^{16}$ Yet even at that time, it was recognized that a codification project would involve some element of development of the law, and that the distinction being drawn was really one of degree. ${ }^{17}$ Consequently, there needed to be some degree of flexibility in the final outcome of a codification project; having the Commission simply issue a "restatement" might not in all instances be appropriate. With that in mind, the ILC Statute provides that for codification projects the Commission should prepare "its drafts in the form of articles" for submission to the General Assembly with a commentary."18 After receiving the views of States, the Commission should then "prepare a final draft and explanatory report," 19 with a recommendation to the General Assembly that it: (a) take no action; (b) take note of or adopt the report by resolution; (c) recommend the draft to Members with a view to the conclusion of a convention; or (d) convoke a conference to conclude a convention. ${ }^{20}$

This type of project, typically referred to as "draft articles," has emerged as the dominant vehicle for the Commission's work, whether the project is thought to be one of codification, of progressive development, or a combination of the two. As indicated above, once the draft articles are completed, the Commission may send them forward with a recommendation that the General Assembly convene a diplomatic conference, whereby States consider, refine, and adopt the articles as a convention. That approach was often taken in the first few decades of the Commission's existence, as is reflected in the Commission's projects that lead to the 1958 law of the sea conventions, the 1961 and 1963 conventions on diplomatic and consular relations, the 1969 convention on the law of treaties, and the 1975 convention on the representation of States in their relations with international organizations, to name but a few.

More recently, the Commission has refrained from recommending the convening of a diplomatic conference, no doubt in part because the General Assembly has become less enthusiastic about launching an expensive multilateral treaty negotiation. Instead, the Commission is more likely simply to recommend pursuit of the project as a convention, recognizing that the General Assembly may wish to refine the Commission's draft articles through work undertaken within its own Sixth Committee. An example would be the Commission's Draft Articles on Jurisdictional Immunities of States and Their Property with commentaries, ${ }^{21}$ which were submitted to the General Assembly in 1991. Rather than

${ }^{16}$ H. Briggs, The International Law Commission (Cornell U. Press, 1965),129-41.

${ }^{17}$ Id. at $135,137-38$.

${ }^{18}$ ILC Statute, Art. 20.

${ }^{19} I d .$, Art. 22.

${ }^{20} I d$., Art. 23(1).

${ }^{21}$ See Report of the International Law Commission on the Work of its Forty-third Session, Gen. Ass. Off. Recs., Forty-sixth Session, Supp. No. 10, at para. 28 (A/46/10). 
convene a diplomatic conference, the General Assembly decided to establish an ad hoc committee of the Sixth Committee to refine the Commission's work, ${ }^{22}$ ultimately leading to the adoption by the Assembly in 2004 of the U.N. Convention on Jurisdictional Immunities of States and Their Property. ${ }^{23}$

The General Assembly, of course, can decline to develop the project as a convention, even in the face of a Commission recommendation that it do so. For example, in 1989 the Commission recommended that the General Assembly convene a diplomatic conference to transform into a convention the Commission's draft articles on the status of the diplomatic courier and the diplomatic bag not accompanied by diplomatic courier. ${ }^{24}$ Although the General Assembly had originally asked the Commission to pursue a protocol to the Vienna Convention on Diplomatic Relations on this topic, ${ }^{25}$ in 1995 the General Assembly decided simply to bring the draft articles to the attention of States and to remind them of the possibility of codification at some future time. ${ }^{26}$ No further work has been undertaken on the matter.

When the General Assembly decides not to pursue a convention despite a recommendation of the Commission to that effect, there may be an implication that the Commission's work was not acceptable to States, which in turn may imply that the project failed to capture properly the law concerning that topic. In part to avoid any such implications, the Commission recently has sent forward its draft articles without any recommendation that they be transformed into convention, most famously with respect to the 2001 Draft Articles on Responsibility of States for Internationally Wrongful Acts. ${ }^{27}$ For that project, the Commission recommended only that the General Assembly "take note" of the draft articles, with the possibility "at a later stage" of transforming them into a convention. ${ }^{28}$ The General Assembly then took note of the draft articles and commended "them to the attention of Governments without prejudice to the question of their future adoption or other appropriate action." 29

The Commission's decision to send the draft articles on state responsibility forward with such a recommendation was understandable. As Frank Berman has noted, "[t]his was an area where there could be quite legitimate doubts whether the international treaty process, in

${ }^{22}$ G.A. Res. 55/150 (Dec. 12, 2000).

${ }^{23}$ G.A. Res. 59/38 (Dec. 2, 2004).

${ }^{24}$ See Report of the International Law Commission on the Work of its Forty-First Session, Gen. Ass. Off. Recs., Forty-fourth Session, Supp. No. 10, at 13 (A/44/10).

${ }^{25}$ G.A. Res. 31/76, para. 4 (Dec. 13, 1976).

${ }^{26}$ G.A. Dec. 50/416 (Dec. 11, 1995).

${ }^{27}$ Report of the International Law Commission on the Work of Its Fifty-third

Session, Gen. Ass. Off. Recs., Fifty-sixth Session, Supp. No. 10, at 26, para. 76 (A/56/10).

${ }^{28} I d$. at 25 , paras. $72-73$.

${ }^{29}$ G.A. Res. 56/83, para. 3 (Dec. 12, 2001); see also G.A. Res. 59/35 (Dec. 2, 2004). 
its current state, was up to a law-making exercise of so major and fundamental a scope, and doubts at the same time whether a treaty negotiation would or would not solidify agreement on the essential rules." ${ }^{\text {"30 }}$ Moreover, given that the Commission had been criticized over the years for being too rigid in assuming that the end product should be a convention, ${ }^{31}$ and given that some of its conventions failed to secure many adherents, ${ }^{32}$ it is unsurprising that the Commission would consider a different path.

Yet the Commission's decision was also controversial, both within and outside the Commission. According to David Caron, "the particular question of form was intensely argued and narrowly decided" in the Commission, with many members supporting a recommendation that would call for the development of a convention. ${ }^{33}$ Caron and others have expressed concern that the Commission's approach may have pushed "the limits of its legitimacy to state what the law is," since several of the draft articles involved a contestable development of the law, rather than just codification. ${ }^{34}$ An approach whereby the Commission blends codification with progressive development is defensible if the ultimate outcome is the adoption by States of a convention, but such blending in a situation where no further State action is envisaged, and with the expectation that the draft articles will simply be seen as "the law," potentially casts the Commission in the role of legislator.

Avoidance of that problem helps explain the statement in the ILC's general commentary to the draft articles on responsibility of international organizations, quoted in the Introduction of this essay. The Commission characterized the project as "draft articles" and made the same recommendation as it had in 2001 with respect to the draft articles on state responsibility, to the effect that the General Assembly simply take note of the draft articles and perhaps "at a later stage" consider their elaboration as a convention. ${ }^{35}$ By doing so, the Commission was offering up the draft articles in a manner that might be perceived as pure codification. Yet the paucity of practice of international organizations on myriad rules contained in the articles, and the uncertainty as to whether State practice could support mutatis mutandis rules relating to international organizations, opened the door to serious accusations that the Commission was overstepping its bounds. By signaling in its commentary that the border between codification and progressive development was more "in the direction of the latter" for several of the articles, and that consequently such articles "do

${ }^{30}$ See F. Berman, 'The ILC within the UN's Legal Framework: Its Relationship with the Sixth Committee', 49 GYIL (2006), 107, at 124.

${ }^{31}$ See, e.g., B. Ramcharan, The International Law Commission (Martinus Nijhoff, 1977), 76; M. El Baradei, T. Franck, \& R. Trachtenberg, The International Law Commission: the Need for a New Direction (UNITAR, 1981), 27.

${ }^{32}$ For a discussion, see I. Sinclair, The International Law Commission (Cambridge, 1987), 39.

${ }^{33}$ D. Caron, 'The ILC Articles on State Responsibility: The Paradoxical Relationship between Form and Authority', 96 AJIL (2002), 857 at 863-64.

${ }^{34} I d$. at 858 .

${ }^{35}$ Report of the International Law Commission on the Work of Its Sixty-Third Session, Gen. Ass. Off. Recs., Sixty-sixth Session, Supp. No. 10, at 53, para. 85 (A/66/10). 
not necessarily yet have the same authority as the corresponding provisions on State responsibility," the Commission sought to neutralize its critics.

As such, the historical arc of the packaging of Commission projects might be seen as coming full circle. Originally, projects would be clearly distinguished as "draft conventions" when they contained significant amounts of progressive development of the law, but that approach was abandoned due to a belief that all projects involve a blend of progressive development and codification. Instead, projects were labeled as "draft articles" but, given the blend of progressive development/codification rules, the Commission sent the project forward with a recommendation that they be transformed into a convention, thereby preserving the legitimacy of the Commission's work. Once the Commission ceased recommending that its projects be transformed into a convention, serious questions of legitimacy arose, for the Commission arguably was advancing its work as pure "codification" when in fact it was not. Claims of illegitimacy were so apparent with respect to the draft articles on responsibility of international organizations, that the Commission reacted by finding a way to re-package the project as containing significant elements of progressive development, much as the characterization of its projects as "draft conventions" was meant to do decades before.

Even so, the Commission appears likely to include language in its commentary characterizing draft articles as "progressive development" only when the articles are so perceived within and (perhaps more importantly) outside the Commission. If there is no particular clamor that the Commission is progressively developing the law on a particular topic, then the approach to packaging taken in 2001 may well be repeated, as occurred with the Commission's 2011 draft articles on the effects of armed conflicts on treaties. ${ }^{36}$

While "draft articles" have been the dominant way of packaging the work products of the Commission, arguably there "are no formal limits to the form of the Commission's output." 37 Indeed, over the years there have been several other forms used (discussed below), which in the future may be of considerable use to the Commission as it straddles its role in codifying and progressively developing the law.

\section{Draft Codes}

On two occasions, the Commission has produced what it characterized as "draft codes." In 1947, as one of its first assignments to the Commission, the General Assembly asked the Commission to "[f]ormulate the principles of international law recognized in the Charter of the Nürnberg Tribunal and in the judgment of the Tribunal" and "[p]repare a draft Code of Offences against the Peace and Security of Mankind". ${ }^{38}$ The discussions at the General Assembly and then within the Commission indicate that this was not intended to be a draft treaty but, instead, an exercise that would assist in the development of an international criminal court. In 1954, the Commission adopted the Draft Code of Offences against the

${ }^{36}$ Id., at 174, para. 97.

${ }^{37}$ M. Wood, "The General Assembly and the International Law Commission: "What Happens to the Commission's Work and Why?", in International Law Between Universalism and Fragmentation (Isabelle Buffard et al., eds., Martinus Nijhoff, 2008), 373 at 375.

${ }^{38}$ G.A. Res. 177(II) (Nov. 21, 1947). 
Peace and Security of Mankind, ${ }^{39}$ consisting of four articles with commentaries. In sending the draft code to the General Assembly, the Commission stated that it "has not considered itself called upon to propose methods by which a code may be given binding force", but instead "has envisaged the possibility of an international tribunal for the trial and punishment of persons committing such offences." 40

In 1981, the General Assembly asked the Commission to resume work of further elaboration of the code. ${ }^{41}$ In conjunction with the development of the Draft Statute for an International Criminal Court in 1996 (noted above), the Commission produced a more detailed Draft Code of Crimes against the Peace and Security of Mankind, again with commentaries. ${ }^{42}$ In sending it to the General Assembly, the Commission noted that it could be transformed into an international convention, could be incorporated as part of the statute of an international criminal court, or could be adopted by a declaration of the General Assembly. ${ }^{43}$ Ultimately, the code helped guide the diplomatic conference that led to adoption of the Rome Statute.

\section{Model Rules}

On one occasion, the Commission characterized its work product as "model rules," which were finalized in 1958 in the Model Rules on Arbitral Procedure, with commentary. Initially, however, the Commission developed "draft articles" on arbitral procedure, which it recommended that the General Assembly transform into a convention. After receiving comments form governments, however, the Assembly invited the Commission to reconsider its approach, which led the special rapporteur to convert the draft articles into "model rules." 44 The Commission then recommended that the Assembly adopt the Commission's report by a resolution, but the Assembly chose instead to just "take note" of the report, bringing it to the attention of States for their consideration as appropriate. ${ }^{45}$

\section{Draft Principles}

On three occasions, the Commission has characterized its work product as "principles," which appear intended to influence the development of international or national law, but not to codify it into specific rules. In 1950, it completed seven Principles of International Law Recognized in the Charter of the Nürnberg Tribunal and in the Judgment of

\footnotetext{
${ }^{39}$ Report of the International Law Commission on the Work of Its Sixth Session, Gen. Ass. Off. Recs., Ninth Session, Supp. No. 9, at 151, para. 54 (A/2693).

${ }^{40}$ Yearbook of the International Law Commission, 1954, Vol. II, at 134, para. 52(d).

${ }^{41}$ G.A. Res. 36/106 (Dec. 10, 1981).

${ }^{42}$ Report of the International Law Commission on the Work of Its Forty-eighth Session, Gen. Ass. Off. Recs., Fifty-first Session, Supp. No. 10, at 17, para. 50 (A/51/10).

43 Id., at 17 , at paras. $47-48$.

${ }^{44}$ I. Sinclair, The International Law Commission (Cambridge, 1987), 37.

${ }^{45}$ G.A. Res. 1262(XIII), para. 2 (Nov. 14, 1958).
} 
the Tribunal, with commentaries, ${ }^{46}$ designed to influence future development of a draft code and creation of an international criminal court. In 2006, it adopted the Draft Principles on the Allocation of Loss in the Case of Transboundary Harm Arising Out of Hazardous Activities, ${ }^{47}$ with commentaries, an effort to promote (but not compel) harmonization of national laws through recommendations rather than hard law. ${ }^{48}$ Also in 2006, the Commission transformed what had originally been envisaged as draft articles into the Guiding Principles Applicable to Unilateral Declarations of States Capable of Creating Legal Obligations, with commentaries. ${ }^{49}$ Characterization of the project as "guiding principles" (and its limitation to just one form of unilateral act - declarations of States) was driven by the recognition that there many different ways in which unilateral acts may have legal effects in international law, making it difficult to establish a set of general rules applicable to all of them. Both sets of "principles" adopted in 2006 were simply commended to the attention of the General Assembly.

VII. Guide to Practice

On one occasion the Commission completed its work in the form of a "guide to practice," which occurred in 2011 with the Guide to Practice on Reservations to Treaties. The Guide to Practice consisted of an introduction, an extensive series of guidelines, commentary, an annex addressing the "dialogue" that should occur when a State files a reservation, and a bibliography. The reason the project was presented in this way, according to the Commission, was "to provide assistance to practitioners of international law, who are often faced with sensitive problems concerning, in particular the validity and effects of reservations to treaties ... and, to a lesser extent, interpretive declarations in respect of treaty provisions .... ."50

The Guide itself was expressly declared not to be binding, ${ }^{51}$ but instead to be a " "toolbox' in which the negotiators of treaties and those responsible for implementing them should find answers to the practical questions raised by reservations ... ."52 Indeed, many of its provisions are in the nature of recommendations that "would not have been included in a traditional set of draft articles intended to be transformed, if appropriate, into a treaty ...". 53

${ }^{46}$ Report of the International Law Commission on the Work of Its Second Session, Gen. Ass. Off. Recs., Fifth Session, Supp. No. 12, at 17, para. 97 (A/1316).

${ }^{47}$ Report of the International Law Commission on the Work of Its Fifty-eighth Session, Gen. Ass. Off. Recs., Sixty-first Session, Supp. No. 10, at 106, para. 85 (A/61/10).

${ }^{48}$ See Report of the International Law Commission on the Work of Its Fifty-Sixth Session, Gen. Ass. Off. Recs., Fifty-ninth Session, Supp. No. 10, at 160 (A/59/10).

49 Report of the International Law Commission on the Work of Its Fifty-eighth Session, Gen. Ass. Off. Recs., Sixty-first Session, Supp. No. 10, at 369, para. 177 (A/61/10).

${ }^{50}$ Report of the International Law Commission on the Work of Its Sixty-Third Session, Gen. Ass. Off. Recs., Sixty-sixth Session, Supp. No. 10, at 34, para. 85 (A/66/10).

${ }^{51} I d$.

${ }^{52} I d$. at 35 .

${ }^{53}$ Id. 


\section{Draft Declaration}

In 1947, the General Assembly asked the Commission to prepare a draft declaration on the broad rights and duties of States ${ }^{54}$ (e.g., setting forth the rule that every State has the right to equality under the law with every other State), which the Commission completed in 1949 with commentaries. ${ }^{55}$ When submitting the draft declaration to the Assembly, the Commission said it was for the Assembly to decide on any further course of action. The Assembly ultimately decided that, due to the limited response by States to the draft declaration, it should postpone consideration of the matter, ${ }^{56}$ after which no further developments occurred.

IX. Resolutions

The Commission is capable of adopting its own resolutions which, inter alia, may make recommendations to State. In 1994, the Commission adopted and transmitted to the General Assembly a Resolution on Confined Transboundary Groundwater, ${ }^{57}$ as a part of its report on the law of the non-navigational uses of international watercourses. In that resolution, the Commission commended "States to be guided by the principles contained in the draft articles on the law of the non-navigational uses of international watercourses, where appropriate, in regulating transboundary groundwater." 58

\section{Reports}

The Commission, of course, submits annual "reports" to the General Assembly, but on rare occasion it has also issued a "report" as a means of concluding its work on a topic, which is typically a discussion of certain aspects of the law in a particular area. In 1950, the Commission submitted to the General Assembly a Report on the Ways and Means for Making the Evidence of Customary International Law More Readily Available. ${ }^{59}$ In 1951, the Commission submitted a Report on Reservations to Multilateral Conventions. ${ }^{60}$ In 1963, it submitted a Report on Extended Participation in General Multilateral Treaties Concluded

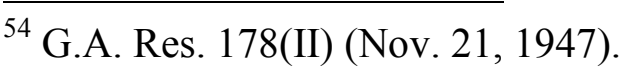

${ }^{55}$ Report of the International Law Commission on the Work of Its First Session, Gen. Ass. Off. Recs., Fourth Session, Supp. No. 10, para. 46 (A/CN.4/13 and Corr. $1-3)$.

${ }^{56}$ G.A. Res. 596 (VI) (Dec. 7, 1951).

${ }^{57}$ See Report of the International Law Commission on the Work of its Forty-Sixth Session, Gen. Ass. Off. Recs., Forty-Ninth Session, Supp. No. 10, at 135 (A/49/10).

${ }^{58}$ Id., para. 1.

${ }^{59}$ Report of the International Law Commission on the Work of Its Second Session, Gen. Ass. Off. Recs., Fifth Session, Supp. No. 12, paras. 24-94 (A/1316).

${ }^{60}$ Report of the International Law Commission on the Work of Its Third Session, Gen. Ass. Off. Recs., Sixth Session, Supp. No. 9, paras. 12-34 (A/1858). 
under the Auspices of the League of Nations. ${ }^{61}$

The report need not be a report of the Commission as a whole. In 1977, the General Assembly invited the Commission to provide "observations" to the Secretary-General to assist in preparation of his report on techniques and procedures in the multilateral treaty process. $^{62}$ In 1979, the Commission submitted to the Secretary-General the Report of a Working Group on Review of the Multilateral Treaty-Making Process, ${ }^{63}$ which focused on the Commission's role in that process. Although the report was of the working group, it was approved by the Commission. ${ }^{64}$ In 2006, the Commission took note of the "conclusions" of its Study Group on the Fragmentation of International Law: Difficulties arising from the Diversification and Expansion of International Law $^{65}$ and commended them to the attention of the General Assembly. Further, the Commission requested that the analytical study finalized by the Chairman of the Study Group (Martti Koskenniemmi) be made available on the website of the Commission and also be published in its Yearbook. ${ }^{66}$

\section{Conclusion}

Over its life, the Commission has developed various ways of packaging its work product. Multiple techniques are available - the format of the project, the characterization of the project in the commentary, and the recommendation for what is to be done with it - for balancing the Commission's roles in advancing the codification and progressive development of international law. While creative use of such techniques to suit the particular topics on the Commission's agenda is to be welcomed, the Commission's authority and legacy ultimately will turn on whether States and other relevant actors view the Commission as adhering to its statutory role, or perceive it as aggregating to itself the role of legislator.

${ }^{61}$ Report of the International Law Commission on the Work of Its Fifteenth Session, Gen. Ass. Off. Recs., Eighteenth Session, Supp., paras. 18-50 (A/5509).

${ }^{62}$ G.A. Res. 32/48 (Dec. 8, 1977).

${ }^{63}$ U.N. Doc. A/CN.4/325 (1979).

${ }^{64}$ Report of the International Law Commission on the Work of Its Thirty-first Session, Gen. Ass. Off. Recs., Thirty-Fourth Session, Supp. No. 10, para. 191 (A/34/10).

${ }^{65}$ Report of the International Law Commission on the Work of Its Fifty-eighth Session, Gen. Ass. Off. Recs., Sixty-first Session, Supp. No. 10, para. 251 (A/61/10).

${ }^{66} I d$., para. 239. 